\title{
Selected problems of sustainable management of rusty soils in forestry
}

\author{
Piotr Sewerniak ${ }^{1 *}$, Michał Jankowski ${ }^{1}$ \\ ${ }^{1}$ Nicolaus Copernicus University in Toruń, Faculty of Earth Science and Spatial Management, Department of Soil Science and Landscape \\ Management, Lwowska 1, 87-100, Toruń, Poland \\ * dr hab. P. Sewerniak, sewern@umk.pl, ORCID iD: https://orcid.org/0000-0002-3071-3963
}

Received: 30.06 .2021

Accepted: 29.10.2021

Associated editor: J. Lasota

\section{Keywords}

Brunic Arenosols

Forest management

Forest soils

Sustainability

Sandy soils

Forest conversion

\begin{abstract}
Since the end of the $18^{\text {th }}$ century Scots pine (Pinus sylvestris) monocultures have been artificially introduced in extensive areas of rusty soils in Central Europe. Such forest management practice has involved, however, several serious problems, like e.g. soil degradation implying the decrease in productivity of forest sites, and the clear increase in the risk of disturbances (pest gradations, fires, wind damages etc.) occurrence. Those troubles have involved the increasing discussion on rational forest management on sandy soils, which are predominant in lowland woodlands of Central Europe. Thus, in this paper we aimed to indicate selected problems of sustainable management of rusty soils in forestry with regard to lowland forests found in the region. The special focus was paid on controversies being related to conversion of pine stands overgrowing these soils, because of its especially high importance for forest management in Central Europe. We postulate that we should intensify the conversion of pure pine stands overgrowing rusty soils into mixed forests, which would reduce the risk of the assumed, and being involved with the ongoing climate changes, problems with the stability of pine forests in Central Europe. The study shows that the current methodology of forest site types diagnosis used in Poland may lead to underestimation of the types, and consequently it consolidates the focus of Polish forestry on breeding pine stands on rusty soils. Following the existing controversies regarding the diagnosis of a forest site type on rusty soils, we postulate that we should more broadly underplant pine stands overgrowing the soils with deciduous trees, regardless of the diagnosed forest site type in forest inventory works. In turn, in conversions executed in maturing conifer stands using a gap cutting, the emphasis should be put on plant diversity. Namely, we highlight in the paper that in the gaps, besides major deciduous species (usually oak and/or beech), the admixture of ameliorative trees should obligatory be introduced (e.g. European hornbeam, Carpinus betulus), which happens to be ignored in practice. We postulate also that logging residues removal, which is still executed in some forest districts in Poland, should be skipped. This practice is especially irrational when it is done in sites dedicated for stand conversion, because it highly increases the risk of mortality and/or of the distinct decrease in growth dynamics of young hardwoods introduced in post-pine sites.
\end{abstract}

\section{Introduction}

Rusty soils (in Polish "gleby rdzawe"; in German "SandBraunerde"; "Brunic Arenosols" according to World Reference Base, IUSS Working Group WRB, 2015) constitute the main soil unit in extensive areas of lowland forests in Central Europe (e.g. Braunerde, 2005; Kabała et al., 2019). However, the rational usage of the rusty soils in forest management appears as a controversial issue, which has been discussed for many decades. From the end of the 18th to the middle of 20th century, conifer monocultures were introduced, regardless of species composition of potential vegetation, in large areas of Central Europe (Olaczek, 1976; Zerbe, 2002). In lowlands, this trend occurred on rusty soils mainly, which had been previously overgrown with forests dominated with deciduous trees (Biały, 1997, 1999; Jankowski,
2003, 2014). The introduction of Scots pine (Pinus sylvestris) pure stands in extensive lowland areas appeared as very controversial, because the monocultures turned out to be labile, and highly susceptible to hazards (Kenk and Guehne, 2001; Spiecker, 2003; Sewerniak and Jankowski, 2017). Consequently, it has been demanded in many papers to converse the pine stands into mixed forests, i.a. to increase forest resistance, as well as the accordance between the existing and potential vegetation (Biały, 1997, 1999; Spiecker, 2003; Jankowski, 2014; Sewerniak, 2016a; Sewerniak and Jankowski, 2017; Sewerniak and Puchałka, 2020).

In forest management, forest stands are indicated for the conversion by the determination of the forest site type. However, the full trophic range of the forest types was allowed to be determined in Poland with regard to rusty soils (Klasyfikacja, 2000; Siedliskowe, 2004). Following the fact that the diagnosed 
forest site types strictly determine species composition of the subsequent stand generation being introduced in a given forest area, this means that the rusty soils are dedicated in Polish forestry for breeding stands of completely different composition: from pine monocultures through mixed stands to pure deciduous forests (Klasyfikacja, 2000; Zasady, 2012). Furthermore, until recently, the diagnosis criterion indicating which rusty soils should be linked to particular forest site types had been very unclear (Biały, 1999; Rutkowski, 2002). Consequently, to increase the objectivity of the diagnosis, the soil trophic index (in Polish: siedliskowy indeks glebowy (SIG)) (Brożek et al., 2008) was officially introduced in Polish forestry to be obligatory used in the diagnosis of forest site types (Instrukcja, 2012). The index includes several soil properties (considered by genetic horizons) being related to soil fertility, and finally a single number (between 4 and 40, the higher value is linked to the higher fertility) is obtained for a given soil (Brożek et al., 2008). The elaborated index ranges determine in forest management works particular forest site types; however, the final diagnosis of the site type for a given plot can be modified (increased or decreased by one fertility class) based on the premises following the features of forest vegetation (growth dynamics and species composition mainly, Instrukcja, 2012). Although the implementation of SIG to forest management works seems generally to be a good step in the improvement of the forest site type determination methodology, the operative Polish forest instructions are still considered as too largely directed for favouring pine monocultures, and the postulate of increasing the rate of the monocultures conversion is highlighted (Sewerniak, 2013; Schelhaas et al., 2015). This seems to be truly reasonable, because it has been reported in some recent papers (e.g. Lindner et al., 2014; Dyderski et al., 2017) that the ongoing climate changes will involve a clear contraction of Pinus sylvestris range in Central Europe in next decades. This trend has been already recently recognized in Polish forests, i.a. overgrowing extensive areas of Brunic Arenosols, as for example by the occurring problems of pine stands stability being related to the massive occurrence of a sharp-dentated bark beetle Ips

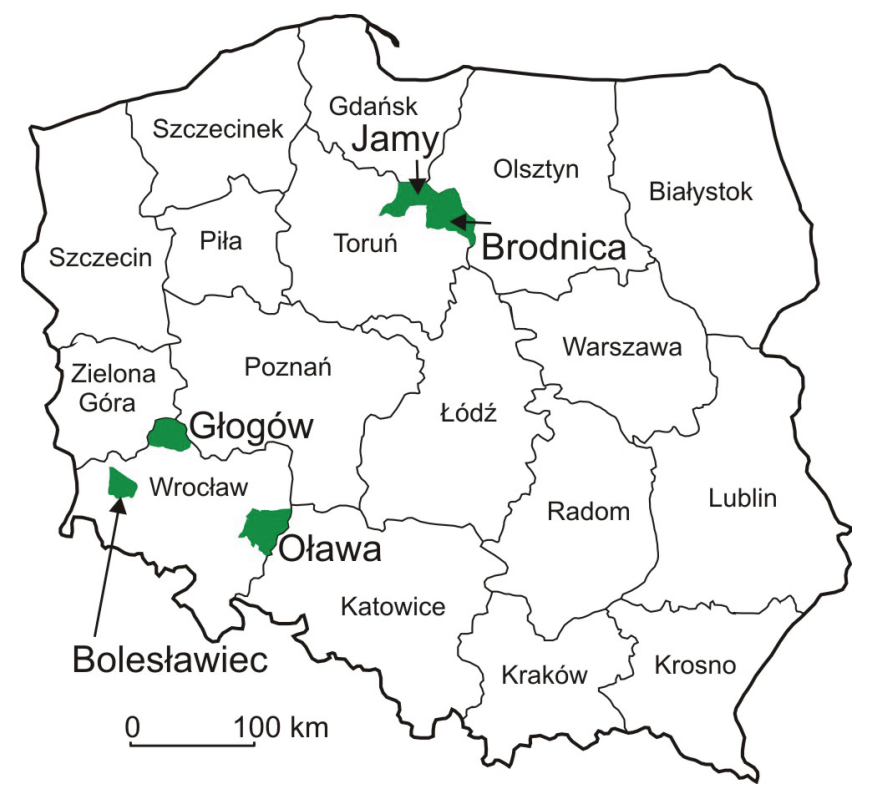

acuminatus and/or of European mistletoe Viscum album (Plewa and Mokrzycki, 2017; Iszkuło et al., 2020). Thus, following the existing ambiguities and controversies regarding the usage of rusty soils in forestry, in this paper we aimed to indicate selected problems of sustainable management of these soils in forestry with regard to the Central European lowland forests. The special focus was paid on problems being related to conversion of pine stands overgrowing rusty soils, because of its especially high importance for forest management in Central Europe.

\section{Materials and methods}

The dilemmas concerning methods used for forest conversion, and the controversial issue of logging residues removal were introduced in this paper based on literature review and our field observations. The only issue presented here based on the detail own authors' research was the problem of the rational forest site type diagnosis regarding the rusty soils. In this part of the study, the analytical soil records gained from forest inventory data (Operat 1997, 1998, 2003, 2004, 2005) were used. At the preliminary step of this work, post-agricultural pedons were excluded from the analysis, because the former agricultural use of a forest soil distinctly affects its properties (Bednarek and Michalska, 1998; Sewerniak, 2016b). Besides, rusty soils being underlaid by fine-textured deposits were also excluded, because such underlying would clearly involve the effect on soil fertility (Sewerniak, 2020). Finally, 101 forest plots with Brunic Arenosols were investigated in the study, which were located in five forest districts: Bolesławiec (16 plots), Brodnica (32), Głogów (12), Jamy (18), Oława (23). Additionally, to show the difference of the trophic conditions between rusty soils and podzolic soils (WRB: "Podzols"), eight representative pedons of the latter soil unit (all situated in the Gniewkowo forest district) were examined also in the research (Operat, 1999). The investigated districts were located in two Regional Directorates of the State Forests: Toruń and Wrocław (Fig. 1). The
Fig. 1. Location of the studied forest districts shown in the map presenting distribution of Regional Directorates of the State Forests in Poland 
study area is characterized by the transitional climate between oceanic and continental. The mean annual temperature in the studied regions is ca. $8.5^{\circ} \mathrm{C}$, and the mean annual precipitation equals ca. $550 \mathrm{~mm}$ (Siedliskowe, 2004).

Soil Trophic Index (SIG) was calculated for each studied plot according to the method elaborated by Brożek et al. (2008). The following soil properties are included in the calculation of the index: content of the $<0.02 \mathrm{~mm}$ textural fraction, total content of basic cations $\left(\mathrm{Ca}^{2+}, \mathrm{Mg}^{2+}, \mathrm{K}^{+}, \mathrm{Na}^{+}\right)$, total content of acidic cations $\left(\mathrm{Al}^{3+}, \mathrm{H}^{+}\right)$, bulk density and thicknesses of soil horizons. The variables are considered by genetic horizons for the $0-150$ $\mathrm{cm}$ soil layer. Besides, content of total organic carbon (TOC) and total nitrogen (Nt) in a topsoil is also included in SIG (Brożek et al., 2008).

Statistical significance between mean values were tested using the software package Statistica 9.0 (StatSoft, USA). The Kruskal-Wallis test was used to examine the significance of differences in SIG values in three subtypes ( $\mathrm{RDb}$ - podzolic rusty soils, RDw - typical rusty soils, RDbr - brown rusty soils) of the studied rusty soils, while the Mann-Whitney U test was employed to assess the significance of differences in SIG values between rusty and podzolic soils. Detected differences were deemed statistically significant at $\mathrm{p}<0.05$.

\section{Results and discussion}

\subsection{Main problems regarding the diagnosis of forest site type}

3.1.1. Some mistakes and controversies regarding diagnosis of soil (sub)type in forest inventory works

The analysis done with regard to extensive areas of inland dunes occurring in the Torun Basin showed that in this region, poor in nutrients and very dry podzolic soils have been wrongly classified in forest inventory works as rusty soils (e.g.
Operat, 1999). The reason can likely be linked to disturbances occurring on dunes which involve the morphological similarity of Podzols to Brunic Arenosols. Namely, each pine production cycle (ca. 100 years) is preceded by soil preparation, which in the past was usually done with usage of a forest plough. Consequently, being typical for Podzols, elluvial horizon (E) is strongly disturbed, and mixed with humus horizon (A), hence finally soil morphology becomes O-A-B-C, which makes a pedon alike a rusty soil. This morphological change is additionally enforced by the occurrence of erosional processes, which affect especially strongly dune ridges (Jankowski, 2003, 2019; Rutkowska, 2019). The rough analysis conducted indicated that the problem of wrong diagnosis of disturbed Podzols as Brunic Arenosols in dunes of the Torun Basin has been very common, and this concerns the area of several thousand hectares. Similar mistakes were also made and consequently reproduced in other dune areas, e.g. the Warsaw Basin (Czępińska-Kamińska, 1986; Janowska, 2001; Konecka-Betley et al., 2002) and the Biebrza Basin (Banaszuk, 1979; Czubaszek, 2006). The impact of that misleading soil diagnosis could be seen as minor; however, in fact, it has serious consequence for forest management. Namely, the mistake consolidates the false opinion (i.a. among practical foresters) that Brunic Arenosols are very poor soils, and consequently they should be dedicated for breeding pure pine stands. However, in fact, the rusty soils feature medium fertility, and their trophic conditions are usually distinctly higher than those of Podzols (Fig. 2).

Another controversy concerns the diagnosis of subtype of rusty soils in forest inventory works. Specifically, according to the Polish operating instructions, brown-rusty soils (RDbr) should predominantly be dedicated for breeding mixed or deciduous stands, while podzolic rusty soils (RDb) for pine forests, mainly (Klasyfikacja, 2000; Zasady 2012). The trophic difference of the subtype can also be seen in the SIG values calculated for the investigated rusty soils (Fig. 3). However, brown-rusty soils, as a result of their earlier degradation by

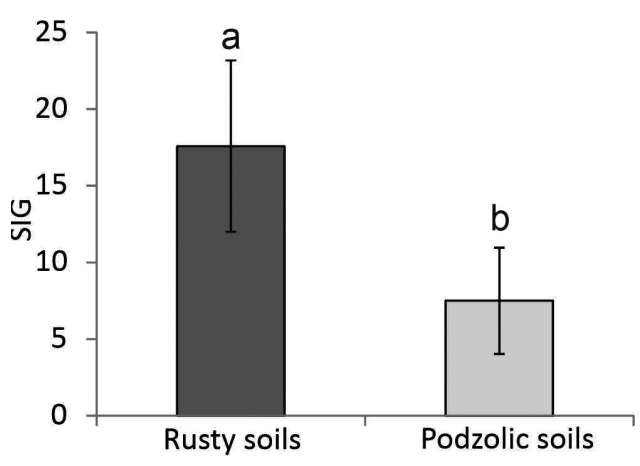

Fig. 2. Mean values $( \pm S D$ ) of Soil Trophic Index (SIG) calculated for investigated rusty and podzolic soils. Different letters above the bars indicate significant difference $(p<0.05)$ between the mean values

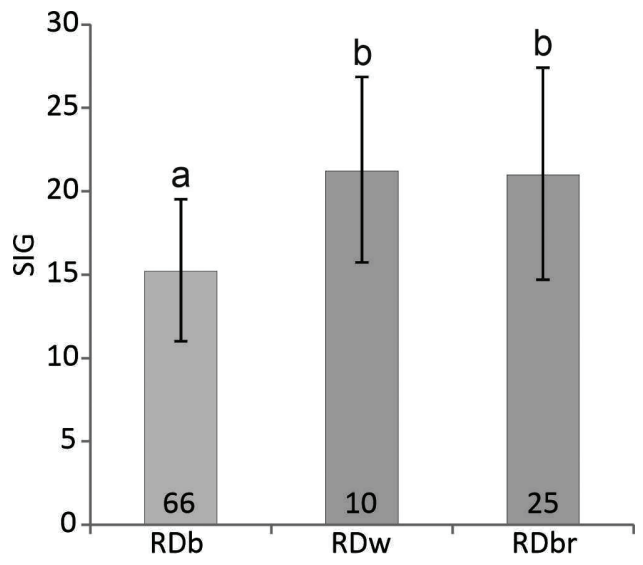

Fig. 3. Mean values $( \pm S D)$ of Soil Trophic Index (SIG) by subtypes of rusty soils (RDb - podzolic rusty soils, RDw - typical rusty soils, RDbr - brown rusty soils). In bars numbers of plots representing each soil subtype are given. Different letters above the bars indicate significant difference $(\mathrm{p}<0.05)$ between the mean values 
the artificially introducing of conifer monocultures (Olaczek, 1976; Biały, 1997, 1999; Jankowski, 2014, 2019) also show podzolization in topsoil, and thus, finally, in inventory works they are defined as podzolic rusty soils. Ultimately, this results in relatively fertile true brown rusty soils being introduced in forest management subsequent generations of almost pure pine stands, which is not consistent with the potential productivity of these soils, as well as with their primary, potential vegetation.

\subsubsection{Implementation of Soil Trophic Index (SIG)}

Our study shows that, generally, the diagnoses of forest site types in the 101 studied plots with rusty soils were higher in inventory works conducted in turn of the 20th and 21st century (Operat, 1997, 1998, 2003, 2004, 2005) than they would be according to the currently operational instruction, in which SIG is used (Instrukcja, 2012). Specifically, when we applied the current method to diagnose the forest site type, the diagnosis was lower by one fertility class in 25 and higher in $4 \%$ plots ( 25 and 4 plots, respectively) when compared to the diagnoses determined during the inventory works (Operat, 1997, 1998, 2003, 2004, 2005). The detailed results obtained for particular subtype of rusty soils and forest site types are shown in table 1 . These results can be seen as surprising, because, especially in the last two decades, the need of pine monocultures conversion has been strongly highlighted in many studies, in which both benefits of such action regarding the increase in forest productivity (Bielak et al., 2014; Pretzsch et al., 2015) as well as the increased resistance to hazards of the mixed stands are indicated (Kenk and Guehne, 2001; Spiecker, 2003; Sierota et al., 2019). Thus, it could be assumed that the current operational instructions should be more clearly aimed at the intensification of conifer monocultures con- version. All the more so because a distinct regress of main conifers occurring in Central Europe (Scots pine and Norway spruce) has been highlighted to occur in the future (Lindner et al., 2014; Dyderski et al., 2017), and the conversion would be in line with the idea of 'adaptive forestry' aiming at adaptive forest management in terms of its adaptation to climate change (Bolte et al., 2009). Thus, our study shows that corrections in use of SIG in forest management instructions are necessary to adjust its usage to modern trends in sustainable forestry.

In figure 4 we show an example of a plot which would be wrongly classified with regard to forest site type if SIG would have been used. Following properties of the pedon occurring in a plot shown in table 2, the calculated SIG value for the soil is 11 , which potentially could involve the diagnosis of a forest site type as mesic coniferous forest (Bśw; Instrukcja, 2012). However, the operating instruction enables to increase the diagnosis of a forest site type if there are premises to do it from the features of forest vegetation (Instrukcja, 2012). Such situation occurs in the studied plot. Specifically, the increase in the diagnosis is supported by the occurrence of such species like Anemone nemorosa and Galeobdolon luteum in a herb layer, and the high contribution of Carpinus betulus in a second tree layer as well as the first site index class measured in forest inventory works for Pinus sylvestris occurring in overstorey (Fig. 4). Thus, finally, according to the currently operating methodology (Instrukcja, 2012) this site would be finally diagnosed as mesic mixed coniferous forest (BMśw). This would imply the distinct dominance (ca. 70\%) of Scots pine in the newly established young plantation in this plot, and the share of broadleaved trees would equal maximum ca. 30\% (Zasady, 2012). Interestingly, the diagnosis made for the plot during forest inventory works at the end of 20th century (Operat, 1998)

Table 1

Number of forest site type diagnosis with regard to particular subtypes of rusty soils determined for the same sites in forest inventory works (Operat, 1997, 1998, 2003, 2004, 2005) (A), and according to the currently operating Polish instruction (Instrukcja, 2012) (B)

\begin{tabular}{|c|c|c|c|c|c|}
\hline \multirow[t]{2}{*}{ Rusty soil subtype } & \multirow{2}{*}{$\begin{array}{l}\text { Forest site type } \\
\text { diagnosis }\end{array}$} & \multicolumn{4}{|c|}{ Forest site type } \\
\hline & & Bśw & BMśw & LMśw & Lśw \\
\hline \multirow[t]{2}{*}{$\mathrm{RDb}$} & A & 10 & 44 & 12 & 0 \\
\hline & $\mathrm{B}$ & 17 & 43 & 6 & 0 \\
\hline \multirow[t]{2}{*}{ RDw } & A & 0 & 8 & 2 & 0 \\
\hline & B & 1 & 5 & 4 & 0 \\
\hline \multirow[t]{2}{*}{ RDbr } & $\mathrm{A}$ & 0 & 0 & 25 & 0 \\
\hline & B & 0 & 8 & 17 & 0 \\
\hline \multirow[t]{2}{*}{ All subtypes } & A & 10 & 52 & 39 & 0 \\
\hline & $\mathrm{B}$ & 18 & 56 & 27 & 0 \\
\hline
\end{tabular}

$\mathrm{RDb}$ - podzolic rusty soils, RDw - typical rusty soils, RDbr - brown rusty soils, Bśw - mesic coniferous forest, BMśw - mesic mixed coniferous forest, LMśw - mesic mixed broadleaved forest, Lśw - mesic broadleaved forest 

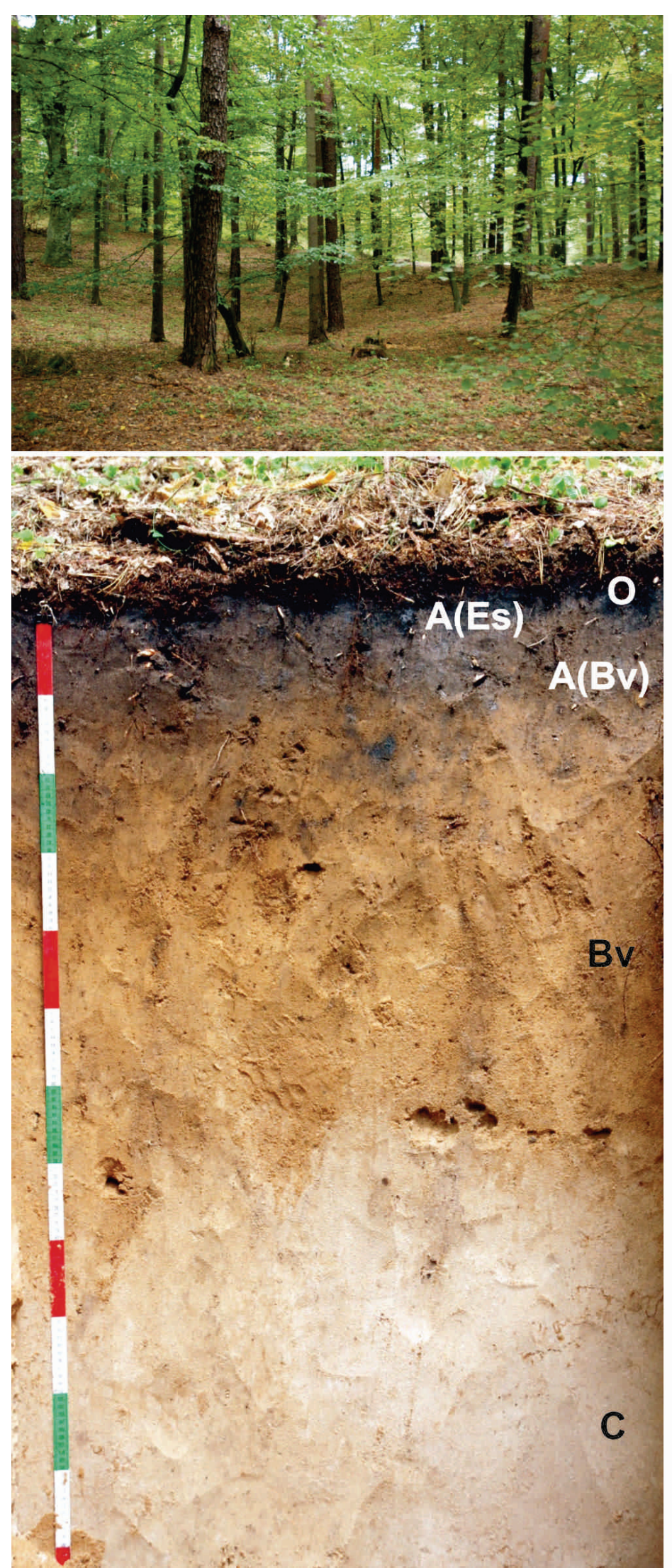

\section{Location:}

Brodnica Lakeland, Jamy forest district, forest section $243 a$

Relief: weakly undulated outwash plain, 88 m. a.s.1.

\section{Vegetation:}

Upper tree layer (cover 75\%): Pinus sylvestris (132 years, Ist site index class) - share $100 \%$ Second layer (80\%): Carpinus betulus $80 \%$, Picea abies $20 \%$ Understorey (25\%): C. betulus $80 \%$, P. abies $20 \%$, Corylus avellana $\mathrm{r}$, Sorbus aucuparia $\mathrm{r}$ Herb layer (30\%): Pteridium aquilinum 2 , Oxalis acetosella 1, Anemone nemorosa +, Calamagrostis arundinacea,+ C. epigejos + , Carex $\mathrm{sp}+$, Deschampsia flexuosa + , Galeobdolon luteum +, Luzula pilosa +, Rubus idaeus + , Rubus sp + , Stellaria holostea + , Vaccinium myrtillus +, Dryopteris carthusiana r, Viola sp r

Moss layer (5\%): Polytrichum commune 1,

Pseudoscleropodium purum + ,

Pleurozium schreberi +

\section{Soil:}

Ol - 8-6 cm - organic horizon, fresh litter Ofh - 6-0 cm - organic horizon, detritus $\mathrm{A}(\mathrm{Es})-0-8 \mathrm{~cm}$ - humus horizon with features of eluviation, loose sand, colour 10YR 2/1 (moist), single-grain structure, numerous roots, unclear border

$\mathrm{A}(\mathrm{Bv})$ - 8-16 cm - humus horizon enriched with iron, loose sand, colour 10YR 2/2, single-grain structure, single roots, transitional border $\mathrm{BV}-16-75 \mathrm{~cm}$ - enrichment horizon siderik, loose sand, colour 10YR 3/4, single-grain structure, single roots, unclear border $\mathrm{C}$ - $>75 \mathrm{~cm}$ - parent material, loose sand, colour 10 YR $5 / 3$, single-grain structure

Fig. 4. Forest ecosystem of a studied plot located in the forest section 243a of the Jamy forest district (the Łąkorz forest division). Numbers/letters following plant and moss names refer to the Braun-Blanquet (1964) contribution scale: $\mathrm{r}-$ one or some specimens, +- sparse and covering small area, 1 - plentiful, but covering $<5 \%$ of the area, 2 - covering $5-25 \%$ of the area 
Table 2

Selected properties of a rusty soil located in the forest section 243a of the Jamy forest district (the Łąkorz forest division; Kminikowski, 2011, completed)

\begin{tabular}{llllllllll}
\hline Horizon & $\begin{array}{l}\text { Depth } \\
(\mathrm{cm})\end{array}$ & $\begin{array}{l}\text { Content of } \\
<0.02 \mathrm{~mm} \\
\text { fraction }(\%)\end{array}$ & $\begin{array}{l}\mathrm{C} \\
\left(\mathrm{g} \mathrm{kg}^{-1}\right)\end{array}$ & $\begin{array}{l}\mathrm{N} \\
\left(\mathrm{g} \mathrm{kg}^{-1}\right)\end{array}$ & $\mathrm{C}: \mathrm{N}$ & $\mathrm{pH}_{\mathrm{H} 2 \mathrm{O}}$ & $\begin{array}{l}\mathrm{BD} \\
\left(\mathrm{g} \mathrm{cm}^{3}\right)\end{array}$ & $\begin{array}{l}\mathrm{BC} \\
\left(\mathrm{cmol}_{\mathrm{c}} \mathrm{kg}^{-1}\right)\end{array}$ & $\begin{array}{l}\mathrm{HA} \\
\left(\mathrm{cmol}_{\mathrm{c}} \mathrm{kg}^{-1}\right)\end{array}$ \\
\hline Ol & $8-6$ & - & 509 & 14.53 & 35 & 5.0 & - & 26.6 & 67.7 \\
Ofh & $6-0$ & - & 370 & 13.29 & 28 & 4.4 & 0.18 & 13.2 & 98.1 \\
$\mathrm{~A}(\mathrm{Es})$ & $0-8$ & 3 & 24.0 & 1.19 & 20 & 4.7 & 1.34 & 0.16 & 4.99 \\
$\mathrm{~A}(\mathrm{Bv})$ & $8-16$ & 4 & 9.2 & 0.56 & 16 & 4.1 & 1.38 & 0.54 & 11.1 \\
$\mathrm{Bv}$ & $16-75$ & 2 & 3.6 & 0.21 & 17 & 4.8 & 1.39 & 0.10 & 3.35 \\
$\mathrm{C}$ & $>75$ & 1 & - & - & - & 5.4 & 1.46 & 0.13 & 1.24 \\
\hline
\end{tabular}

$\mathrm{BD}$ - bulk density, $\mathrm{BC}$ - sum of exchangeable basic cations $\left(\mathrm{Ca}^{2+}, \mathrm{Mg}^{2+}, \mathrm{K}^{+}, \mathrm{Na}^{+}\right), \mathrm{HA}$ - hydrolytic acidity

was a class higher. Namely, it was mesic mixed broadleaved forest (LMśw), which enabled the introduction of the higher share of deciduous trees (ca. 50\%) in a next forest generation in this plot (Zasady, 2012).

\subsection{Dilemmas concerning methods used for forest conversion}

The gap cutting and conifer stand underplanting with deciduous trees are the main methods used in Polish forestry to convert pure pine stands into mixed forests (Zasady, 2012). The former method is used in maturing, while the latter in relatively young (up to ca. 50 years) stands.

The idea of the gap cutting is to form relatively regularly arranged gaps in a transformed pine stand in which deciduous species are introduced (usually artificially by planting). The total area of the gaps in a single stand constitutes $30-40 \%$ of the total stand area (Zasady, 2012). The operational instruction indicates clearly that in gaps, which are usually strongly dominated with oak or beech, admixture of deciduous species should also be introduced, especially of hornbeam and lime (Tilia cordata and T. platyphyllos) (Zasady, 2012). However, as it can be seen from field observations, the recommendation in some forest districts is neglected, and the particular gaps are entirely overplanted with one species (oak or beech). This is done probably because of the presumed fear of introducing species like Carpinus betulus, because of its assumed competition to major trees like Quercus sp. However, as it was shown by Andrzejczyk et al. (2014), although in young plantations hornbeam is on average higher than oak, a growth inhibition of oak by hornbeam is not significant. Furthermore, it must be keep in mind that (especially just regarding sandy ecosystems as those with Brunic Arenosols) the productivity of a forest site is conditioned strongly by the efficient turnover of nutrients between plants and a soil (Prusinkiewicz, 1970), and conse- quently there are many studies reporting highly productive forest stands found in efficiently functioning ecosystems with rusty soils (e.g. Borowiec, 1961; Sewerniak, 2013; Andrzejczyk and Sewerniak, 2016). In turn, hornbeam distinctly facilitates the turnover, because the decomposition rate of its leaves is much higher than not only conifers, but also such broadleaved trees like oak, beech and lime (Gołąb, 1978; Dziadowiec, 1987). Thus, introducing such ameliorative species like Carpinus betulus involves site regeneration after the adverse effect of conifers, and finally promotes growth dynamics of young trees in stand conversion. Moreover, in many recent studies the positive relation between forest species diversity, and stand productivity has been highlighted (Bielak et al., 2014; Pretzsch et al., 2015; Liang et al., 2016; Sewerniak, 2020), which should also strongly encourage practical foresters to introduce admixture species in gaps in forest conversion.

In this study, we also want to introduce an important dilemma regarding the selection of pine stands for deciduous species underplanting. Usually, beech and oak are used for the action; however, because of its higher tolerance to shadow conditions, as well as the lower risk of the occurrence of serious damages caused by cervids, the former species is preferably used. There are the two main types of the underplantings: i) done in sites of medium/high fertility, in which the introduced trees are presumed to constitute timber stock in the future, and ii) executed in sites of low fertility, in which the site is presumed to be too poor to enable growth of the introduced hardwoods into the main crop, and thus they are expected to stay in undergrowth. However, as it has been commonly observed in practice, even the latter underplanting category expresses high growth dynamics, which can be linked to the underestimation of site fertility in forest inventory works (sites of relatively high potential productivity are commonly wrongly classified as poor mesic coniferous site type, Bśw). Thus, we strongly recommend that the selection of pine stands for the underplantings should be done 
based on soil unit rather than on forest site type diagnosed in the inventory works. Specifically, we propose that the occurrence of Brunic Arenoslos should be a strong argument for the pine stand underplanting regardless of forest site type diagnosed in forest inventory works. This would enable to select for the action much more extensive area in Polish forests as hitherto it has been done. However, following the presumed for the next decades and being related to ongoing climate change, contraction of Scots pine range in Central Europe (Lindner et al., 2014; Dyderski et al., 2017), as well as several related serious problems which have already appeared in Poland regarding the species in recent years (Plewa and Mokrzycki, 2017; Iszkuło et al., 2020), in our opinion this would be strongly rational.

Finally, we would like to highlight that there are strong arguments from natural processes occurring in pine stands overgrowing rusty soils, which show the real productivity potential of these soils, and consequently justify extending the area of stand conversions on the rusty soils. Namely, in extensive areas, even of entire (not underlaid with fine textured deposits) rusty soils, broadleaved trees have naturally encroached by natural succession (Olaczek, 1976; Biały, 1997; Zerbe, 2002). This is observed, for example, in extensive areas of rusty soils in the Brodnica Landscape Park (Mendyk et al., 2014). In turn, it must be kept in mind that one of the obvious conditions of the process is the occurrence of seed sources. Unless they occur, pine stands become very poor in number of plant species, and it is really difficult to believe that the potential vegetation for these sites had been dominated with broadleaved trees. With regard to Polish forests, such situation concerns clearly western part of the country, in which the stimulated primarily by Prussians, the introduction of conifer monocultures has had especially long history (Olaczek, 1976).

\subsection{Problem of logging residues removal}

Organic matter plays an essential role in productivity of sandy soils in forestry (Prusinkiewicz, 1970). This is because of low potential of sand in absorbing rainwater as well as general its low fertility and extremely low sorption capacity (Pokojska, 1986, 1992) when compared to fine textured deposits. Organic matter is the only substance that significantly counteracts these shortcomings of sandy soils. Thus, caused by any reason breakdown of its alimentation to mineral topsoil in Brunic Arenosols involves serious disruption in forest ecosystem functioning, which strongly and adversely affects also site productivity. This phenomenon has been relatively well recognized with regard to litter raking, which for centuries had been commonly executed in numerous European forests (Dzwonko and Gawroński, 2002; Vild et al., 2018). Recently, it has been the increased trend to harvest the logging residues (small branches, needles etc.) in Polish forests (Gornowicz et al., 2021). However, such a practice already several decades ago was criticized as the action negatively affecting growth dynamics of newly established young plantations (Prusinkiewicz et al., 1983). It was highlighted that the removal of logging residues deprives forest ecosystems of vital pool of nutrients being active in their turnover between plants and a soil, which, consequently, negatively affects forest productivity (Kowalkowski, 1983; Prusinkiewicz et al., 1983; Sewerniak, 2011). Besides, the effective turnover of nutrients between plants and a soil makes even sandy soils relatively highly productive for forestry (Prusinkiewicz, 1970). Thus, undoubtedly, logging residues removal in forest ecosystems with rusty soils is not in line with sustainable forestry, and especially the action should be skipped in sites, where stand conversion is planned. Execution of the removal, and thus the elimination of substantial part of the active pool of nutrients from their turnover, before the deciduous trees introducing would be entirely illogical and discordant with the idea of sustainable forestry. However, unfortunately, such a practice has been implemented in some forest districts. Hence, it can be assumed that next to such objective troubles in re-establishing hardwoods in post-coniferous sites like, for example, soil acidification (Harasimiuk and Groblewski, 2005), the action can explain low growth dynamics of young deciduous trees being introduced on rusty soils.

\section{Summary}

In Central Europe, Scots pine monocultures were artificially introduced in extensive areas of rusty soils (Olaczek, 1976; Zerbe, 2002). However, this forest management practice has led to soil degradation (Biały, 1997, 1999; Jankowski, 2014), as well as it has led to the decrease in productivity of forest stands (Sewerniak, 2013). Besides, the monospecific conifer stands have been recognized as labile ecosystems being susceptible to hazards (Kenk and Guehne, 2001; Spiecker, 2003). Indeed, following the effect of the ongoing climate change, the occurrence of Scots pine is highlighted to be shrunk in Central Europe in next decades (Lindner et al., 2014; Dyderski et al., 2017), and the trend has already been noticed in increasing pine mortality caused by factors being until now of minor importance (Plewa and Mokrzycki, 2017; Iszkuło et al., 2020). Thus, to minimalize the risk of large-area problems with stability of pine stands in Central Europe, it is rational to intensify the conversion of the stands into mixed forests. With this end in view; however, the appropriate corrections for the usage of soil trophic index (SIG, Brożek et al., 2008) in operating Polish instructions on forest site survey (e.g. Instrukcja, 2012) should be introduced. The conversion of Pinus sylvestris stands should be primarily done by pine stands underplanting with deciduous species, which should cover more extensive areas of rusty soils than so far it has been done. In turn, the emphasis should be put on plant diversity when gap cutting is used for the conversion in maturing/mature pine stands. Namely, in the gaps apart from major deciduous species (usually oak and/or beech) the admixture of ameliorative trees should obligatory be introduced (e.g. hornbeam). In the paper, we also highlight that the allowance for 
logging residues removal, especially before introducing young deciduous trees in post-pine sites, is extremely irrational, because the action strongly disturbs the nutrients' turnover between plants and a soil, and thus, finally, can drastically negatively affect the productivity of sandy forest ecosystems.

\section{Acknowledgments}

We thank Robert Kminikowski for his help in field and laboratory works, as well as Michał Dąbrowski and Adam Michalski for their help in laboratory analyses. We are also grateful to Sławomir Jaskólski for improving the English text.

\section{References}

Andrzejczyk, T., Sewerniak, P., 2016. Soils and forest site types of the seed stands of common (Quercus robur) and sessile (Q. petraea) oaks in Poland. Sylwan 160(8), 674-683. (in Polish with English abstract) https://doi.org/10.26202/sylwan.2016001

Andrzejczyk, T., Dzwonkowski, M., Pawłowski, M., Działak, R., 2014. Effect of lateral shelter on a height growth of sessile oak (Quercus petraea) and common hornbeam (Carpinus betulus) in young growth phase. Sylwan 158(10), 723-732. (in Polish with English abstract) https://doi.org/10.26202/sylwan.2014004

Banaszuk, H., 1979. Genesis and evolution of the soil cover on dunes of the Biebrza basin. Roczniki Gleboznawcze - Soil Science Annual, 30(2), 111-142. (in Polish with English abstract)

Bednarek, R., Michalska, M., 1998, Effect of agricultural use on morphology and properties of rusty soils in the surroundings of Bachotek lake in the Brodnica Lakeland. Zeszyty Problemowe Postępu Nauk Rolniczych 460, 487-497. (in Polish with English abstract)

Biały, K., 1997. The problem of soil degradation in forest ecosystems of the Drawa National Park. [In:] Pawlaczyk, P., (Ed.), Soils and vegetation of forest ecosystems in the Drawa National Park. Sorus, Poznań, 25-42. (in Polish with English abstract)

Biały, K., 1999. Optionality in discrimination of forest site types and planning final species compositions in stands on podzolic soils. Sylwan 143(5), 65-72. (in Polish with English abstract)

Bielak, K., Dudzińska, M., Pretzsch, H., 2014. Mixed stands of Scots pine (Pinus sylvestris L.) and Norway spruce [Picea abies (L.) Karst] can be more productive than monocultures. Evidence from over 100 years of observation of long-term experiments. Forest Systems 23(3), 573-589. http://dx.doi.org/10.5424/fs/2014233-06195

Bolte, A., Ammer, C., Löf, M., Madsen, P., Nabuurs, G.-J., Schall, P., Spathelf, P., Rock, J., 2009. Adaptive forest management in central Europe: Climate change impacts, strategies and integrative concept. Scandinavian Journal of Forest Research, 24, 473-482. https://doi. org/10.1080/02827580903418224

Borowiec, S., 1961. Leached Brown Soils in Tabórz Pine sites. Sylwan 105(5), 31-41. (in Polish with English abstract)

Braun-Blanquet, J., 1964. Pflanzensoziologie. Grundzüder Vegetationskunde. Springer-Verlag, Wien-New York.

Braunerde. Steckbriefe Brandenburger Böden, 2005. Ministerium für Ländliche Entwicklung, Umwelt und Verbraucherschutz. Potsdam.

Brożek, S., Zwydak, M., Lasota, J., 2008. Numerical index of trophic variants of Podzols and Arenosols subtypes. Roczniki Gleboznawcze - Soil Science Annual 59(1), 7-17. (in Polish with English abstract)
Czępińska-Kamińska, D., 1986. Zależność między rzeźbą terenu a typami gleb obszarów wydmowych Puszczy Kampinoskiej. Wydawnictwo SGGW, Warszawa, 5-72. (in Polish with English abstract)

Czubaszek, R., 2006. The soils of the inpeatland dunes in the Biebrza River Valley and the Narew River Valley. Zeszyty Naukowe Politechniki Białostockiej 17, 41-62. (in Polish with English abstract)

Dyderski, M., Paź, S., Frelich, L.E., Jagodziński, A.M., 2017. How much does climate change threaten European forest tree species distributions? Global Change Biology 24, 1150-1163. https://doi.org/10.1111/ gcb.13925

Dziadowiec, H., 1987. The decomposition of plant litter fall in an oakhornbeam forest and an oak-pine mixed forest of the Białowieża National Park. Acta Societatis Botanicorum Poloniae 56(1), 169-185. https://doi.org/10.5586/asbp.1987.019

Dzwonko, Z., Gawroński, S., 2002. Effect of litter removal on species richness and acidification of a mixed oak-pine woodland. Biological Conservation 106, 389-398. https://doi.org/10.1016/S00063207(01)00266-X

Gołąb, Z., 1978. Chemical changes occurring in beech and hornbeam leaves in their decomposition course in natural conditions. Roczniki Gleboznawcze - Soil Science Annual 29(2), 31-41. (in Polish with English abstract)

Gornowicz, R. , Pilarek, Z., Kwaśna, H., Łakomy, P., Kuźmiński, R., Jakubowski, J., Stempski, W., 2021. Biomass of young Scots pine stand on dystrophic site type with regard to the method of logging residues management and way of soil preparation. Sylwan 165(1), 21-29. https://doi.org/10.26202/sylwan.2020094

Harasimiuk, A., Groblewski, J., 2005. Why the young oaks do not grow? On the spruce negative impact on forest site. Roczniki Gleboznawcze - Soil Science Annual 56(1/2), 67-75.

Instrukcja urządzania lasu. Część II. Instrukcja wyróżniania i kartowania w Lasach Państwowych typów siedliskowych lasu oraz zbiorowisk roślinnych. Centrum Informacyjne Lasów Państwowych, Warszawa 2012. (in Polish)

Iszkuło, G., Armatys, L., Dering, M., Ksepko, M., Tomaszewski, D., Ważna, A., Giertych, M.J., 2020. Mistletoe as a threat to the health state of coniferous forest. Sylwan 164(3), 226-236. https://doi.org/10.26202/ sylwan.2019121

IUSS Working Group WRB, 2015. World Reference Base for Soil Resources 2014 (Update 2015). International Soil Classification System for Naming Soils and Creating Legends for Soil Maps. World Soil Resources Reports No. 106. FAO, Rome.

Jankowski, M., 2003. Historia rozwoju pokrywy glebowej obszarów wydmowych Kotliny Toruńskiej. PhD thesis, UMK, Torun. (in Polish)

Jankowski, M., 2014. Bielicowanie jako wtórny proces w glebach rdzawych Brodnickiego Parku Krajobrazowego. [In:] Świtoniak, M., Jankowski, M., Bednarek, R. (Eds.), Antropogeniczne przekształcenia pokrywy glebowej Brodnickiego Parku Krajobrazowego. Wydawnictwo Naukowe UMK, Toruń, 9-24. (in Polish)

Jankowski, M., 2019. Pokrywa glebowa. [In:] Sewerniak P., Holc J. (Eds.), Przyroda poligonu toruńskiego stan badań i problemy ochrony. Wydawnictwo Naukowe UMK, Torun, 27-42. (in Polish)

Janowska, E., 2001. Origin and properties of of rusty soils in the area of the central polish glaciation. Wydawnictwo Fundacja Rozwój SGGW. (in Polish with English abstract)

Kabała, C. et al., 2019. Polish Soil Classification, 6th edition - principles, classification scheme and correlations. Soil Science Annual 70(1), 71-97.

Kenk, G., Guehne, S., 2001. Management of transformation in central Europe. Forest Ecology and Management 151, 107-119. http://dx.doi. org/10.1016/S0378-1127(00)00701-5 
Klasyfikacja gleb leśnych Polski. CILP, Warszawa 2000. (in Polish)

Kminikowski, R., 2011. Geograficzne prawidłowości rozmieszczenia gleb w północnej części zlewni Skarlanki w granicach Brodnickiego Parku Kraobrazowego. Msc Thesis, UMK, Toruń. (in Polish)

Konecka-Betley, K., Czępińska-Kamińska, D., Janowska, E., Okołowicz, M., 2002. Gleby strefy ochrony ścisłej i częściowej w Rezerwacie Biosfery - Puszcza Kampinoska. Roczniki Gleboznawcze - Soil Science Annual 53(3/4), 5-21.

Kowalkowski, A., 1983. Influence of the utilization of biomass in pine stands on the circulation of mineral nutrients and the features of soils on poor coniferous forest sites. Prace IBL 598, 68-85.

Liang, J. et al., 2016. Positive biodiversity-productivity relationship predominant in global forests. Science 354, aaf8957. https://doi. org/10.1126/science.aaf8957

Lindner, M., Fitzgerald, J.B., Zimmermann, N.E., Reyer, C., Delzon, S., van der Maaten, E., Schelhaas, M.-J., Lasch, P., Eggers, J., van der Maaten-Theunissen, M., Suckow, F., Psomas, A., Poulter, B., Hanewinkel, M., 2014. Climate change and European forests: What do we know, what are the uncertainties, and what are the implications for forest management? Journal of Environmental Management 146, 69-83. http://dx.doi.org/10.1016/j.jenvman.2014.07.030

Mendyk, Ł., Sewerniak, P., Strzyżewski, T., Rutkowska, P., Sykuła, M., Szałek, J., Kondratowska, M., 2014. Mapa zgodności pokrywy glebowej z roślinnością. [In:] Świtoniak, M., Jankowski, M., Bednarek, R. (Eds.), Antropogeniczne przekształcenia pokrywy glebowej Brodnickiego Parku Krajobrazowego. Wydawnictwo Naukowe UMK, Toruń, 111-127. (in Polish)

Olaczek, 1976. Changes in the vegetation cover of Poland since the middle of XIX century. Zeszyty Problemowe Postępów Nauk Rolniczych 177, 369-408. (in Polish with English summary)

Operat, 1998, 2003, 2004, 2005. Operat glebowo-siedliskowy. Nadleśnictwo Brodnica, Oława, Bolesławiec, Głogów. Biuro Usług Ekologicznych i Urządzeniowo-Leśnych „Operat”, Toruń. (in Polish)

Operat, 1997. Operat glebowo-siedliskowy. Nadleśnictwo Jamy. Zakład Usług Ekologicznych i Urządzeniowo-Leśnych. mgr inż. Andrzej Kosakowski, Poznań. (in Polish)

Operat, 1999. Operat glebowo-siedliskowy. Nadleśnictwo Gniewkowo. Biuro Usług Techniczno-Leśnych "Butel”, Toruń. (in Polish)

Plewa, R., Mokrzycki, T., 2017. Occurrence, biology, and economic importance of the sharp-dentated bark beetle Ips acuminatus (Gyllenhal, 1827) (Coleoptera, Curculionidae, Scolytinae) in Poland. Sylwan 161(8), 619-629. https://doi.org/10.26202/sylwan.2017077

Pokojska, U., 1986. The role of humus in formation of the reaction, the buffer properties and the cation-exchange capacity of forest soils. Roczniki Gleboznawcze - Soil Science Annual 37(2/3), 249-263. (in Polish with English abstract)

Pokojska, U., 1992. Adsorption and exchange of cations by forest humus. Wydawnictwo UMK. (in Polish with English abstract)

Pretzsch, H. et. al., 2015. Growth and yield of mixed versus pure stands of Scots pine (Pinus sylvestris L.) and European beech (Fagus sylvati$c a$ L.) analysed along a productivity gradient through Europe. European Journal of Forest Research 134, 927-947. http://doi.org/10.1007/ s10342-015-0900-4

Pruskinkiewicz, Z., 1970. Actual problems of the protection of forest soils in Poland. Sylwan 114(12), 1-6. (in Polish with English abstract)

Prusinkiewicz, Z., Kowalkowski, A., Królikowaki, L., 1983. The protection and recultivation of forest soils. Roczniki Gleboznawcze - Soil
Science Annual 34(3), 185-201. (in Polish with English abstract)

Rutkowska, P.A., 2019. Przebieg procesu bielicowania w cyklu uprawy monokultur sosnowych w wybranych obszarach piaszczystych Polski Północnej. PhD thesis, UMK, Toruń. (in Polish)

Rutkowski, P., 2002. The research of differentiation forest units connected with sandy soils. Acta Scientiarum Polonorum 1(1), 73-85. (in Polish with English abstract)

Schelhaas, M.-J., Nabuurs, G-J., Hengeveld, G., Reyer, C., Hanewinkel, M., Zimmermann, N.E., Cullmann, D., 2015. Alternative forest management strategies to account for climate change-induced productivity and species suitability changes in Europe. Regional Environmental Change 15, 1581-1594. https://doi.org/10.1007/s10113-015-0788-z

Sewerniak, P., 2011. Pozyskiwanie biomasy a gleba leśna. Las Polski 4, 10-12. (in Polish)

Sewerniak, P., 2013. Site index of Scots pine stands in south-western Poland in relation to forest site types and soil units. Sylwan 157(7), 516-525. (in Polish with English abstract) https://doi.org/10.26202/ sylwan.2013028

Sewerniak, P., 2016a. Impact of land relief on site index and growth parameters of Scots pine stands on inland dunes in the Torun Basin. Sylwan 160(8), 647-655. (in Polish with English abstract) https://doi. org/10.26202/sylwan.2016056

Sewerniak, P., 2016b. The effect of former agricultural use on the forest soil features against problems with mapping of post-agricultural forest habitats. [In:] Zielony, R. (Ed.), Siedliska leśne zmienione i zniekształcone. CILP, Warszawa, 43-62. (in Polish with English summary)

Sewerniak, P., 2020. Plant species richness or soil fertility: which affects more the productivity of Scots pine in Central Europe? Annals of Forest Research 63(2), 57-73. https://doi.org/10.15287/afr.2020.2003

Sewerniak, P., Jankowski, M., 2017. Topographically-controlled site conditions drive vegetation pattern on inland dunes in Poland. Acta Oecologica 82, 52-60. https://doi.org/10.1016/j.actao.2017.06.003

Sewerniak, P., Puchałka, R., 2020. Topographically induced variation of microclimatic and soil conditions drives ground vegetation diversity in managed Scots pine stands on inland dunes. Agricultural and Forest Meteorology 291, 108054. https://doi.org/10.1016/ j.agrformet.2020.108054

Siedliskowe podstawy hodowli lasu. OR-WLP w Bedoniu, Warszawa 2004.

Sierota, Z., Grodzki, W., Szczepkowski, A., 2019. Abiotic and Biotic Disturbances Affecting Forest Health in Poland over the Past 30 Years: Impacts of Climate and Forest Management. Forests 10, 75. https:// doi.org/10.3390/f10010075

Spiecker, H., 2003. Silvicultural management in maintaining biodiversity and resistance of forests in Europe - temperate zone. Journal of Environmental Management 67, 55-65. http://dx.doi.org/10.1016/ S0301-4797(02)00188-3

Vild, O., Šipoš, J., Szabo, P., Macek, M., Chudomelová, M., Kopecky, M., Suchánkowá, S., 2018. Legacy of historical litter raking in temperate forest plant communities. Journal of Vegetation Sciences 29, 596-606. https://doi:10.1111/jvs.12642

Zasady hodowli lasu. CILP, Warszawa 2012.

Zerbe, S., 2002. Restoration of natural broad-leaved woodland in Central Europe on sites with coniferous forest plantations. Forest Ecology and Management 167, 27-42. http://dx.doi.org/10.1016/S03781127(01)00686-7. 


\section{Wybrane problemy racjonalnego użytkowania gleb rdzawych w gospodarce leśnej}

\section{Słowa kluczowe}

Gleby rdzawe

Gospodarka leśna

Gleby leśne

Zrównoważony rozwój

Gleby piaszczyste

Przebudowa drzewostanów

\section{Streszczenie}

Praca ma na celu zasygnalizowanie najważniejszych problemów racjonalnego użytkowania gleb rdzawych w gospodarce leśnej w odniesieniu do niżowych lasów Europy Środkowej. Gleby rdzawe stanowią dominujący typ gleb w tej części kontynentu, jednak ich ocena pod kątem kierunku użytkowania w gospodarce leśnej jest wciąż kwestią niejednoznaczną. Wyraźnie jest to widoczne w pracach siedliskowych, w których na glebach rdzawych dopuszczalna jest diagnoza całego troficznego spektrum siedlisk świeżych (od boru do lasu świeżego). Sprawia to, że gleby, które powstały w ramach tego samego procesu glebotwórczego, przeznaczane są do hodowli skrajnie różnych pod względem gatunkowym drzewostanów (od monokultur sosnowych po lasy liściaste). Na rozległych areałach gleb rdzawych prowadzi się, często od ponad 200 lat, gospodarkę leśną w oparciu o sztuczne nasadzenia monokultur sosnowych, co prowadzi do zniekształcenia/degradacji siedlisk, obniża ich możliwości produkcyjne, a także znacznie utrudnia poprawną ocenę tych możliwości. Obowiązująca obecnie metodyka diagnozowania siedlisk w Polsce, w odniesieniu do wielu gleb rdzawych, przyczynia się do pogłębiania tych problemów przez ukierunkowanie diagnozy typu siedliskowego lasu w stronę siedlisk borowych. Tymczasem, w obliczu wyraźnie negatywnych prognoz wpływu zachodzących zmian klimatu na występowanie sosny w Europie Środkowej, a także wiązanych z tymi zmianami narastającymi zagrożeniami biotycznymi trwałości drzewostanów sosnowych (np. presja kornika ostrozębnego i jemioły pospolitej), należałoby zintensyfikować przebudowę monokultur iglastych porastających gleby rdzawe na lasy o zróżnicowanym składzie gatunkowym. W pracy postulujemy, aby ta intensyfikacja miała miejsce szczególnie w drodze znacznie powszechniejszego niż jest to wykonywane obecnie podsadzania gatunkami liściastymi drzewostanów sosnowych młodszych i średnich klas wieku. W przeprowadzanych przebudowach należy rozważyć, aby w większym stopniu uwzględniać domieszkę gatunków fitomelioracyjnych (np. graba pospolitego) w celu m.in. usprawnienia obiegu składników pokarmowych w układzie fitocenoza-gleba, a także ograniczyć bardzo szkodliwy pod względem utrzymania potencjału produkcyjnego siedlisk leśnych (szczególnie właśnie w odniesieniu do gleb piaszczystych) proceder pozyskiwania pozostałości biomasy leśnej po wykonywanych cięciach w drzewostanach. Postulat zwiększenia powierzchni przebudowywanych drzewostanów znajduje także uzasadnienie w obserwowanym powszechnie spontanicznym pojawianiu się gatunków liściastych w monokulturach sosny na glebach rdzawych. 